\title{
The Impact of Distributive Justice, Procedural Justice, and Affective Commitment on Turnover Intention among Public and Private Sector Employees in Malaysia
}

\author{
G. C. W. Gim and N. Mat Desa
}

\begin{abstract}
This paper examined the impact of distributive and procedural justice on turnover intention via affective commitment. Specifically, it is predicted that when the distributive and procedural justice relating to compensation are perceived to be fair, employees are more affectively committed to the organization and expressed lower turnover intention. A total of 226 respondents throughout Malaysia participated in this study. Partial least squares of structural equation modeling was used in the study. The results showed that distributive and procedural justice was significantly and positively related to affective commitment, which in turn was significantly and negatively related to turnover intention. It also revealed that affective commitment fully mediates the relationship between distributive and procedural justice with turnover intention. The results also showed that the type of organization that an employee works in does not moderate the relationship between affective commitment and turnover intention. It is therefore important for organizations from both the public and private sectors to reward its employees equitably and to implement fair compensation procedures to foster higher affective commitment in order to improve employees' retention in the workplace.
\end{abstract}

Index Terms-distributive justice, procedural justice, affective commitment, turnover intention.

\section{INTRODUCTION}

Employee turnover in the workplace is getting more prevalent as employees are getting more demanding from their employment relationship. The competitive labor market and low unemployment rate in Malaysia may have induced employees to job-hop [1]. The rising trend of job-hopping can be witnessed through the increased employee turnover rates in Malaysia from 10\% in 2009 to $15.9 \%$ in 2011 in a mere two years [2]. The turnover problem is more prevalent among employees in the private sector. Therefore, the continuing rise of employee turnover rate should not be neglected by employers.

Among public sector employees in Malaysia, research on turnover intention are usually carried out on academics [3], [4] or nurses [5]. There is scarcity of research on turnover among public sector employees other than academics and nurses. Such public sector employees should not be neglected because after all they are also human resources that are part of the government service that provide services of all kinds to the general public. These employees should not be neglected because the attrition of these public sector employees may

Manuscript received September 13, 2013; revised November 30, 2013.

The authors are with Universiti Sains Malaysia, Malaysia (e-mail: gabrielgim83@gmail.com, nasina@usm.my). pose problem as well as it could harm the sustainability of the government services provided to the citizens of Malaysia. Therefore, this study included public sector employees in Malaysia to examine turnover intention.

Employees' turnover is hardly beneficial to organizations because it is costly due to higher recruitment, increased training, and lost productivity [6]. According to Malaysia Human Resources Minister Datuk Seri Dr S. Subramaniam, the issue of job-hopping among young employees is getting serious [7] indicating the escalating turnover problem in Malaysia. Understanding the work-related antecedents to turnover intention may help organizations to improve the work environment to the desired level in order to enhance retention. Therefore, turnover intention deserved research attention because it is a direct antecedent and a proxy for actual turnover behaviour [8].

Research has shown that compensation is an important factor in retaining employees [9], [10]. The importance of the fairness of how rewards are distributed to the employees and the procedures that comes with it should be investigated for its impacts on attitudinal and behavioural intention outcomes So, there is a need to examine perception of organizational justice with the focus on compensation in relation to affective commitment and turnover intention.

This research hopes to fill in the research gap on the turnover intention literature and to add further understanding to the impacts of perception of organizational justice and affective commitment on the behavioural intention to quitting among employees in both the private and public sector.

This research attempts to answer the research questions below:

- Is there a relationship between organizational justice (distributive justice and procedural justice) and affective commitment?

- Is there a relationship between affective commitment and turnover intention?

- Does affective commitment mediate the relationship between organizational justice (distributive justice and procedural justice) and turnover intention?

- Does organization sector moderate the relationship between affective commitment and turnover intention?

\section{LITERATURE REVIEW}

\section{A. Turnover Intention}

Research undertaken on employee turnover is important because turnover is costly to organizations. Turnover 
intention refers to the relative strength of an employee's intention to leave the organization [11]. Price [12] has identified various antecedents to turnover intention which include job satisfaction, organizational commitment, job involvement, distributive justice, and job stress, to name a few.

Turnover intention is examined as the dependent variable in this study because Fishbein and Ajzen [13] postulated that behavioural intention precedes actual behaviour and empirical studies [8], [14], [15] have shown that turnover intention is an antecedent to actual turnover behaviour. It is also more beneficial to focus on turnover intention because remedial actions can still be taken before the actual turnover materialized [16]. Hence, turnover intention is justified to be examined as a proxy for turnover behaviour.

\section{B. Affective Commitment}

Organizational commitment represents an employee's attachment to the employing organization [17] and it comprises three dimensions, which are affective commitment, continuance commitment and normative commitment [18]. This research will only examine affective commitment as a mediator.

Meyer and Allen [18], define affective commitment as "employee's emotional attachment to, identification with, and involvement in the organization". Meyer and Herscovitch [19] argued that affective commitment is developed when the employees becomes involved, shared similar values, and derived an identity from the organization. Affective commitment is the most widely used form of commitment [20] and most importantly, affective commitment is the strongest predictor for turnover intention compared to continuance or normative commitment [21]. Hence, this study will only focus on affective commitment.

\section{Organizational Justice}

The perception of justice at the workplace is an important perception that could influence the attitude and behaviour of employees [22]. There is lack of consensus among scholars on the number of dimensions for organizational justice. Organizational justice can be divided into three dimensions [23], [24] or four dimensions [22], [25]. Based on the construct validation by Colquitt [26], the four dimensions are distributive justice, procedural justice, interpersonal justice, and informational justice. For this study, only distributive and procedural justice are examined because they form the structural aspects of organizational justice [27].

Distributive justice refers to fairness of the distributed outcomes such as rewards while procedural justice refers to the fairness of the procedure of how the outcomes are distributed [28]. There are six criteria that frame up the fairness of the procedures, which are consistency, bias suppression, accuracy of information, correctability, representation, and ethicality [29]. The six criteria should be fulfilled for a procedure to be perceived as fair.

Based on the conservation of resources (COR) theory [30], the perception of injustice could disrupt the attitude and behaviour of employees in organization because such perception could deplete one's resources [25] and such perception could lead to counterproductive behaviour and withdrawal behaviour [22], [23]. Past studies have shown that organizational justice is significantly and negatively related to turnover intention [22], [23].

\section{Development of Hypotheses and Theoretical Framework}

The COR theory [30] is applied in explaining the theoretical framework of this study. Based on the COR theory, an employee who perceive injustice will lose resources and in the attempt to recoup the lost resources, further energies are expanded resulting in a vicious cycle of further loss of resources. Eventually, the employee will withdraw from the organization to prevent further loss of resources. Turnover intention and affective commitment are conceptualized as the behavioural intention and attitudinal strain resulting from the perception of organizational injustice. The theoretical framework of the study is shown in Fig. 1 below.

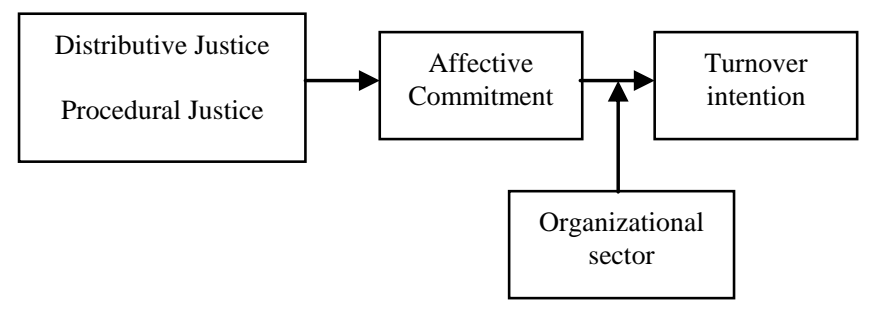

Fig. 1. Theoretical framework of the study

Meta-analysis by Cohen-Charash and Spector [23] and Colquitt et al. [22] revealed that both distributive justice and procedural justice have significant positive relationship with organizational commitment. The meta-analysis by Meyer et al. [21] also revealed that distributive and procedural justice have significant positive relationship specifically with affective commitment. Employees who perceive that compensation is fairly distributed and fair procedures are involved in the distribution of compensation are expected to be affectively committed to the organization. Hence,

H1: Distributive justice is positively related to affective commitment.

$\mathrm{H}$ 2: Procedural justice is positively related to affective commitment.

Over the years, organizational commitment has been identified to be a significant predictor of turnover intention [17], [21], [31]. Other studies [21], [32], [33] have also demonstrated that affective commitment is significantly and negatively related to turnover intention. Employees who are not affectively committed to the organization will have stronger tendencies to leave the organization [17]. Hence,

H3: Affective commitment is negatively related to turnover intention.

Based on the behavioural intention model posited by Fishbein and Ajzen [13], attitude mediates the relationship between beliefs and behavioural intention. Furthermore, Poon [32] and Ramamoorthy and Flood [33] reported that affective commitment mediates the relationship between organizational justice and turnover intention. Hence,

H4: Affective commitment mediates the relationship between distributive justice and turnover intention.

H5: Affective commitment mediates the relationship 
between procedural justice and turnover intention.

In Taiwan, turnover intention is found to be lower among public sector employees compared to private sector employees [34]. It is also expected that turnover intention among private sector employees in Malaysia to be stronger compared to public sector employees. Hence,

H6: The relationship between affective commitment and turnover intention is moderated by the type of organization sector the employees work in where the relationship will be stronger for private sector employees than for public sector employees.

\section{ReSEARCh Methodology}

\section{A. Research Design}

Questionnaires were distributed to working adults studying at the School of Distance Education of Universiti Sains Malaysia. The respondents are from West and East Malaysia. The questionnaires were distributed on a convenience sampling basis.

Partial least squares of structural equation modeling was used to assess the goodness of measures and to test the hypotheses for this study. The mediation was tested using the bootstrapping approach as suggested by Preacher and Hayes [35].

\section{B. Measurement}

Distributive justice (four items) and procedural justice (seven items) were assessed based on the measures developed by Colquitt [26]. The Cronbach's alphas were both 0.93 for distributive justice and procedural justice [26]. The scale was measured using a seven-point Likert scale ranging from (1) "strongly disagree" to (7) "strongly agree".

Affective commitment was measured based on the scales developed by Meyer, Allen, and Smith [36] containing six items. The Cronbach's alpha for the scale is 0.82 [36]. The measures were measured using a five-point Likert scale ranging from (1) "strongly disagree" to (5) "strongly agree".

Turnover intention was measured based on the scales developed by Wayne, Shore, and Liden [37] containing five items. The Cronbach's alpha for the scale is 0.89 [37]. The measures were measured using a five-point Likert scale ranging from (1) "strongly disagree" to (5) "strongly agree".

\section{ANALYSIS AND FINDINGS}

\section{A. Demographic Profiles}

The major highlights of the demographic profiles of the respondents are shown below in Table I. A total of 226 working adults responded to the questionnaire. The majority of the respondents are aged 30 and below $(55.8 \%)$, are female $(72.6 \%)$, are Malay (82.3\%), are working between four to six years $(36.7 \%)$, are earning below RM2,001 (42.5\%), and are working in the public sector (73.9\%).

\section{B. Goodness of Measures}

Construct validity, convergent validity, discriminant validity, and reliability analysis were used to assess the goodness of measures for the study variables. For the purpose of construct validity, Table II below shows the factor loadings for each construct and any loadings that are above 0.50 on a particular construct are deemed significant [38] Loadings below 0.50 were deleted and there were no reported cross loadings. Hence, the constructs were valid for this study.

TABLE I: DEMOGRAPHIC PROFILES OF RESPONDENTS

\begin{tabular}{|c|c|c|c|}
\hline $\begin{array}{l}\text { Demographic } \\
\text { variables }\end{array}$ & Categories & Frequency & $\begin{array}{c}\text { Percentage } \\
(\%)\end{array}$ \\
\hline \multirow[t]{4}{*}{ Age } & 30 and below & 126 & 55.8 \\
\hline & $31-40$ years & 90 & 39.8 \\
\hline & $41-50$ years & 9 & 4.0 \\
\hline & 51 and above & 1 & .4 \\
\hline \multirow[t]{2}{*}{ Gender } & Male & 62 & 27.4 \\
\hline & Female & 164 & 72.6 \\
\hline \multirow[t]{4}{*}{ Race } & Malay & 186 & 82.3 \\
\hline & Chinese & 15 & 6.6 \\
\hline & Indian & 8 & 3.5 \\
\hline & Others & 17 & 7.5 \\
\hline \multirow[t]{5}{*}{$\begin{array}{l}\text { Organizational } \\
\text { Tenure }\end{array}$} & $\begin{array}{c}\text { Less than } 1 \\
\text { year }\end{array}$ & 4 & 1.8 \\
\hline & $1-3$ years & 45 & 19.9 \\
\hline & 4-6 years & 83 & 36.7 \\
\hline & $7-9$ years & 49 & 21.7 \\
\hline & $\begin{array}{c}\text { More than } 9 \\
\text { years }\end{array}$ & 45 & 19.9 \\
\hline \multirow[t]{5}{*}{ Monthly salary } & $\begin{array}{c}\text { Below } \\
\text { RM2,001 } \\
\end{array}$ & 96 & 42.5 \\
\hline & $\begin{array}{l}\text { RM2,001 to } \\
\text { RM3,000 }\end{array}$ & 94 & 41.6 \\
\hline & $\begin{array}{l}\text { RM3,001 to } \\
\text { RM4,000 }\end{array}$ & 20 & 8.8 \\
\hline & $\begin{array}{l}\text { RM4,001 to } \\
\text { RM5,000 }\end{array}$ & 10 & 4.4 \\
\hline & $\begin{array}{l}\text { More than } \\
\text { RM5,000 }\end{array}$ & 6 & 2.7 \\
\hline \multirow[t]{2}{*}{ Sector } & Public sector & 167 & 73.9 \\
\hline & Private sector & 59 & 26.1 \\
\hline
\end{tabular}

TABLE II: LOADINGS AND CROSS LOADINGS

\begin{tabular}{|c|c|c|c|c|}
\hline & $\begin{array}{c}\text { Affective } \\
\text { Commitment }\end{array}$ & $\begin{array}{c}\text { Distributive } \\
\text { Justice }\end{array}$ & $\begin{array}{c}\text { Procedural } \\
\text { Justice }\end{array}$ & $\begin{array}{c}\text { Turnover } \\
\text { Intention }\end{array}$ \\
\hline A3 & $\mathbf{0 . 7 6 7}$ & 0.217 & 0.244 & -0.449 \\
\hline A5 & $\mathbf{0 . 8 3 5}$ & 0.275 & 0.265 & -0.502 \\
\hline A6 & $\mathbf{0 . 6 8 2}$ & 0.376 & 0.298 & -0.332 \\
\hline D1 & 0.365 & $\mathbf{0 . 8 5 6}$ & 0.401 & -0.230 \\
\hline D2 & 0.325 & $\mathbf{0 . 9 1 2}$ & 0.410 & -0.175 \\
\hline D3 & 0.318 & $\mathbf{0 . 9 1 6}$ & 0.417 & -0.178 \\
\hline D4 & 0.339 & $\mathbf{0 . 9 1 0}$ & 0.479 & -0.218 \\
\hline P1 & 0.248 & 0.350 & $\mathbf{0 . 6 9 9}$ & -0.109 \\
\hline P2 & 0.248 & 0.306 & $\mathbf{0 . 7 2 8}$ & -0.089 \\
\hline P3 & 0.320 & 0.379 & $\mathbf{0 . 7 5 9}$ & -0.169 \\
\hline P4 & 0.289 & 0.380 & $\mathbf{0 . 8 4 6}$ & -0.227 \\
\hline P5 & 0.237 & 0.350 & $\mathbf{0 . 8 1 6}$ & -0.201 \\
\hline P6 & 0.116 & 0.242 & $\mathbf{0 . 6 2 3}$ & -0.091 \\
\hline P7 & 0.316 & 0.454 & $\mathbf{0 . 8 1 3}$ & -0.123 \\
\hline TI1 & -0.553 & -0.180 & -0.229 & $\mathbf{0 . 8 5 6}$ \\
\hline TI2 & -0.322 & -0.051 & -0.107 & $\mathbf{0 . 6 2 0}$ \\
\hline TI3 & -0.417 & -0.206 & -0.075 & $\mathbf{0 . 8 1 5}$ \\
\hline TI5 & -0.383 & -0.229 & -0.157 & $\mathbf{0 . 7 3 1}$ \\
\hline & & & & \\
\hline
\end{tabular}

Factor loadings, composite reliability (CR), and average variance extracted (AVE) are looked into to assess convergent validity,. Table III below showed that all factor loadings are above the recommended value of 0.50 , the composite reliabilities are above the recommended value of 0.70 , and the AVEs are above the recommended value of 0.50 [38]. Thus, the convergent validity of the constructs 
were supported.

To assess discriminant validity, the correlations between the measures are compared with the square root of the AVEs. As shown in Table IV below, all of the correlations between the measures were lower than the square root of the AVEs which are shown on the diagonals. Therefore, the items measuring the constructs for this study have adequate discriminant validity.

Reliability was also assessed via Cronbach's alpha coefficient, which should have a value higher than the recommended value of 0.60 [39]. Table III below showed that all constructs have alpha values of above the recommended value and therefore, the measures are reliable.

TABLE III: RESULTS OF MEASUREMENT MODEL

\begin{tabular}{|c|c|c|c|c|c|}
\hline Construct & Items & Loadings & $\begin{array}{c}\text { Cronbach's } \\
\text { Alpha }\end{array}$ & AVE & CR \\
\hline \multirow{4}{*}{$\begin{array}{l}\text { Distributive } \\
\text { Justice }\end{array}$} & D1 & 0.856 & 0.920 & 0.808 & 0.944 \\
\hline & D2 & 0.912 & & & \\
\hline & D3 & 0.916 & & & \\
\hline & D4 & 0.910 & & & \\
\hline \multirow{7}{*}{$\begin{array}{l}\text { Procedural } \\
\text { Justice }\end{array}$} & $\mathrm{P} 1$ & 0.699 & 0.877 & 0.575 & 0.904 \\
\hline & $\mathrm{P} 2$ & 0.728 & & & \\
\hline & P3 & 0.759 & & & \\
\hline & $\mathrm{P} 4$ & 0.846 & & & \\
\hline & P5 & 0.816 & & & \\
\hline & P6 & 0.623 & & & \\
\hline & P7 & 0.813 & & & \\
\hline \multirow{3}{*}{$\begin{array}{l}\text { Affective } \\
\text { Commitment }\end{array}$} & A3 & 0.767 & 0.639 & 0.584 & 0.807 \\
\hline & A5 & 0.835 & & & \\
\hline & A6 & 0.682 & & & \\
\hline \multirow{4}{*}{$\begin{array}{l}\text { Turnover } \\
\text { Intention }\end{array}$} & TI1 & 0.856 & 0.754 & 0.579 & 0.844 \\
\hline & TI2 & 0.620 & & & \\
\hline & TI3 & 0.815 & & & \\
\hline & TI5 & 0.731 & & & \\
\hline
\end{tabular}

Note: a. Composite reliability $(\mathrm{CR})=$ (square of the summation of the factor loadings $) /\{$ (square of the summation of the factor loadings) + (square of the summation of the error variances) $\}$

b. Average variance extracted $(\mathrm{AVE})=($ summation of the square of the factor loadings $) /\{$ (summation of the square of the factor loadings) + (summation of the error variances) $\}$

TABLE IV: DISCRIMINANT VALIDITY OF CONSTRUCTS

\begin{tabular}{|l|c|c|c|c|}
\hline & $\mathbf{1}$ & $\mathbf{2}$ & $\mathbf{3}$ & $\mathbf{4}$ \\
\hline 1. Distributive Justice & $\mathbf{0 . 8 9 9}$ & & & \\
\hline 2. Procedural Justice & 0.475 & $\mathbf{0 . 7 5 8}$ & & \\
\hline 3. Affective Commitment & 0.376 & 0.351 & $\mathbf{0 . 7 6 4}$ & \\
\hline 4. Turnover Intention & -0.224 & -0.195 & -0.565 & $\mathbf{0 . 7 6 1}$ \\
\hline
\end{tabular}

Note: The bolded diagonals represent square root of the AVE while the off-diagonals represent the correlation.

\section{Hypothesis Testing}

Path analysis was performed to test the hypotheses. The $R^{2}$ value for affective commitment was 0.18 meaning that $18 \%$ of the variance in affective commitment is explained by distributive and procedural justice. Looking at each predictors individually as shown in Table $\mathrm{V}$, distributive justice $(\beta=0.271, p<0.01)$ was a significant predictor for affective commitment. Additionally, procedural justice $(\beta=$ $0.222, p<0.01$ ) was also found to be a significant predictor for affective commitment. So, $\mathrm{H} 1$ and $\mathrm{H} 2$ were supported.

With turnover intention as the dependent variable, the $R^{2}$ value revealed that $32 \%$ of the variance for turnover intention was explained by affective commitment. Affective commitment $(\beta=-0.565, p<0.01)$ was found to be a significant predictor for turnover intention as shown in Table VI. So, H3 was supported.

TABLE V: COEFFICIENTS BETA AND $R^{2}$ FOR AFFECTIVE COMMITMENT

\begin{tabular}{|l|c|}
\hline Exogenous Variables & Coefficient ( $\mathbf{\beta})$ \\
\hline Distributive Justice & $0.271^{* * *}$ \\
Procedural Justice & $0.222^{* * *}$ \\
\hline$R^{2}$ & 0.18 \\
\hline$* * * p<0.01, * * p<0.05, * p<0.10$ &
\end{tabular}

TABLE VI: COEFFICIENT BETA AND $R^{2}$ FOR TURNOVER INTENTION

\begin{tabular}{|l|c|}
\hline Exogenous Variable & Coefficient ( $\boldsymbol{\beta})$ \\
\hline Affective Commitment & $-0.565^{* * * *}$ \\
\hline$R^{2}$ & 0.32 \\
$* * * p<0.01, * * p<0.05, * p<0.10$ &
\end{tabular}

Bootstrapping of 500 resamples was used to test the indirect effect of distributive and procedural justice on turnover intention via affective commitment as the mediator. From Table VII below, it showed that after bootstrapping, both paths from distributive and procedural justice have significant indirect impacts on turnover intention via affective commitment. Therefore, H4 and H5 were supported.

TABLE VII: INDIRECT IMPACTS

\begin{tabular}{|c|c|c|c|c|c|c|}
\hline H & Relationship & $\begin{array}{c}\text { Pat } \\
\text { h A } \\
(\boldsymbol{\beta})\end{array}$ & $\begin{array}{c}\text { Path } \\
\mathbf{B} \\
(\boldsymbol{\beta})\end{array}$ & $\begin{array}{c}\text { Standard } \\
\text { Deviation } \\
\text { (After Boot } \\
\text { strap) }\end{array}$ & $\begin{array}{c}\text { t-value } \\
\text { (After } \\
\text { Boot } \\
\text { strap) }\end{array}$ & $\begin{array}{c}\text { Indir } \\
\text { ect } \\
\text { Impa } \\
\text { ct }\end{array}$ \\
\hline $\mathrm{H} 4$ & $\begin{array}{c}\mathrm{DJ} \rightarrow \mathrm{AC} \\
\rightarrow \mathrm{TI}\end{array}$ & $\begin{array}{c}0.2 \\
71 * \\
* *\end{array}$ & $\begin{array}{c}-0.565 \\
* * *\end{array}$ & 0.041 & $3.697 * * *$ & Yes \\
\hline $\mathrm{H} 5$ & $\begin{array}{c}\mathrm{PJ} \rightarrow \mathrm{AC} \\
\rightarrow \mathrm{TI}\end{array}$ & $\begin{array}{c}0.2 \\
22\end{array}$ & $\begin{array}{c}-0.565 \\
* * *\end{array}$ & 0.041 & $3.024 * * *$ & Yes \\
\hline
\end{tabular}

For path coefficients, $* * * p<0.01, * * p<0.05, * p<0.10$

For t-values, *** $p<0.01, * * p<0.05, * p<0.10$

Looking at Table VIII, the path coefficient for distributive justice $(\beta=-0.182, p<0.05)$ was significant without the mediator and it became non-significant $(\beta=-0.016, p>0.10)$ when affective commitment was added to the path. Similarly, the path coefficient for procedural justice $(\beta=-0.124, p<$ $0.10)$ was significant without the mediator and it became non-significant $(\beta=-0.004, p>0.10)$ when affective commitment was added to the path. So, it showed that affective commitment fully mediated the paths from distributive and procedural justice to turnover intention.

TABLE VIII: FULL OR PARTIAL MEDIATION

\begin{tabular}{cccccc}
\hline \multicolumn{5}{c}{ TABLE VIII: FULL OR PARTIAL MEDIATION } \\
Hypothesis & $\begin{array}{c}\text { Path } \\
\text { Coefficient } \\
(\boldsymbol{\beta}) \\
(\text { Without } \\
\text { Mediation) }\end{array}$ & $\begin{array}{c}\text { Path } \\
\text { Coefficient } \\
(\boldsymbol{\beta}) \text { (With } \\
\text { Mediation) }\end{array}$ & $\begin{array}{c}\text { Indirect } \\
\text { Impact }\end{array}$ & $\begin{array}{c}\text { Full or } \\
\text { Partial } \\
\text { Mediation }\end{array}$ \\
\hline $\mathrm{H} 4$ & $\begin{array}{c}\text { DJ } \rightarrow \text { AC } \\
\rightarrow \text { TI } \\
\mathrm{HJ} \rightarrow \text { AC } \\
\rightarrow \text { TI }\end{array}$ & $-0.182 * *$ & -0.016 & Yes & $\begin{array}{c}\text { Full } \\
\text { Mediation } \\
\text { Full } \\
\text { Mediation }\end{array}$ \\
\hline$* * * p<0.01, * * p<0.05, * p<0.10$ & $-0.124 *$ & -0.004 & Yes & \\
\hline
\end{tabular}

To assess the moderating effect of the type of organization sector (private or public sector) on the relationship between affective commitment and turnover intention, a direct path from the type of organization sector towards turnover intention was created and the interaction effect between affective commitment and the type of organization sector was 
also created. The direct effect of the type of organization sector $(\beta=0.07, p>0.10)$ and the interaction effect between the type of organization sector and affective commitment $(\beta=$ $-0.01, p>0.10)$ on turnover intention were both non-significant. Hence, H6 was not supported.

Table IX shows the summary of the hypotheses tested and whether it was supported or not supported.

TABLE IX: SUMMARY OF HYPOTHESES TESTING

\begin{tabular}{lcccc}
\hline \multicolumn{4}{c}{ TABLE IX: SUMMARY OF HYPOTHESES TESTING } \\
\hline H & Relationship & $\begin{array}{c}\text { Coefficient } \\
(\boldsymbol{\beta})\end{array}$ & t-value & Decision \\
\hline H1 & DJ $\rightarrow$ AC & 0.271 & $4.018 * * *$ & Supported \\
H2 & PJ $\rightarrow$ AC & 0.222 & $3.158 * * *$ & Supported \\
H3 & AC $\rightarrow$ TI & -0.565 & $13.221 * * *$ & Supported \\
H4 & DJ $\rightarrow$ AC $\rightarrow$ TI & & $3.697 * * *$ & Supported \\
H5 & PJ $\rightarrow$ AC $\rightarrow$ TI & & $3.024 * * *$ & Supported \\
H6 & (Organization Sector $\mathrm{x}$ & & 0.036 & Not \\
& AC) $\rightarrow$ TI & & & supported \\
\hline$* * *<0.01, * *<0.05 * p<0.10$ & &
\end{tabular}

$* * * p<0.01, * * p<0.05, * p<0.10$

\section{DISCUSSION}

Consistent with previous research [21], [32], [33], this study revealed that both distributive and procedural justice have significant positive relationship with affective commitment, which in turn has a significant negative impact on turnover intention. The results also showed that affective commitment mediates the relationship between distributive and procedural justice with turnover intention, which is consistent with previous studies [32], [33]. The results indicated that when there is fairness in the outcomes of rewards and how the rewards are allocated, employees would be affectively committed to their organization, and as a result they will be less likely to intent to quit the organization. Practically in relation to compensation fairness, management should reward its employees equitably and the allocation procedures should be applied equitably to enhance the affective commitment of its employees in order to retain them.

Practitioners should learn that employees do not just assess the fairness of the compensation they received (outcomes) but also the procedures involved in the distribution of the compensation. Both distributive justice and procedural justice are equally important to employees at the workplace. Given this, practitioners should not neglect the Leventhal's six criteria when allocating compensation to employees to ensure procedural fairness.

Another important finding here revealed that the type of organization sectors the employees work in does not moderate the relationship between affective commitment and turnover intention. Although employees in the public sector are expected to have weaker intention to quit, the results showed that even public sector employees have similar intention to quit with those working in the private sector if they are not affectively committed to the organization. As a result, this is consistent with a large number of prior studies that established the significant relationship between affective commitment and turnover intention. Therefore, a moderating variable will not interact in this relationship. Practically, this should be a cause of concern to the government because attrition of employees in the public sector may affect the sustainability of the provision of services to the citizens of
Malaysia. Thus, the government should not neglect the welfare of public sector employees and a better salary scheme should be laid out to retain them. Additionally, researchers should also pay more attention to the commitment and turnover intention of employees in the public sector given the revealed findings.

\section{LIMITATION}

The limitation of this study is that the samples in this study were limited to working adults studying at the School of Distance Education, USM. Such samples may imply that they are already not satisfied with their current salary and have higher intention to quit and that is why they decided to further their tertiary education to gain higher earnings in the future. Thus, the generalization of the results to the rest of the population may have limitation.

\section{CONCLUSION}

Despite the limitations, this research showed the importance of compensation fairness, including the allocation procedures, in fostering affective commitment and reducing turnover intention among employees from both the public and private sectors. Thus in conclusion, the ability of organizations to retain their employees depends on the fairness of the compensation and the allocation procedures involved.

\section{REFERENCES}

[1] S. L. Choi, P. Perumal, and M. A. Ajagbe, "The impact of human resource management practices on employees' turnover intention: A conceptual model," Interdisciplinary Journal of Contemporary Research in Business, vol. 4, pp. 629-641, 2012.

[2] L. Goh. (2012, February 19). Why job-hoppers hop. [Online] Available:

http://thestar.com.my/news/story.asp?file=/2012/2/19/nation/2012021 $9070805 \&$ sec $=$ nation

[3] M. K. Idris, M. P. O’Driscoll, and M. H. Anderson, "Longitudinal mediation effects of strain on the relationships between role stressors and employees' withdrawal responses," Stress and Health, vol. 27, pp. 403-412, 2011

[4] A. Hassan and J. Hashim, "Role of organizational justice in determining work outcomes of national and expatriate academic staff in Malaysia," International Journal of Commerce and Management, vol. 21, pp. 82-93, 2011.

[5] M. M. Alam and J. F. Mohammad, "Level of job satisfaction and intent to leave among Malaysian nurses," Business Intelligence Journal, vol. 3, pp. 123-137, 2010.

[6] M. H. Huang and Z. H. Cheng, "The effects of inter-role conflicts on turnover intention among frontline service providers: Does gender matter?" The Service Industries Journal, vol. 32, pp. 367-381, 2012.

[7] New Straits Times. (2012). Job-hopping trend alarming. [Online]. Available:

http://www.nst.com.my/nation/general/minister-job-hopping-trend-ala rming-1.86718\#ixzz2MVFurMMS

[8] R. P. Steel and N. K. Ovalle, "A review and meta-analysis of research on the relationship between behavioural intentions and employee turnover," Journal of Applied Psychology, vol. 69, pp. 673-686, 1984

[9] M. A. Campion, "Meaning and measurement of turnover: Comparison of alternative measures and recommendations for research," Journal of Applied Psychology, vol. 76, pp. 199-212, 1991.

[10] R. K. Chiu, V. W. M. Luk, and T. L. P. Tang, "Retaining and motivating employees. Compensation preferences in Hong Kong and China," Personnel Review, vol. 31, pp. 402-431, 2002.

[11] P. W. Hom and R. W. Griffeth, "Structural equations modeling test of a turnover theory: Cross-sectional and longitudinal analyses," Journal of Applied Psychology, vol. 76, pp. 350-366, 1991.

[12] J. L. Price, "Reflections on the determinants of voluntary turnover," International Journal of Manpower, vol. 22, pp. 600-624, 2001. 
[13] M. Fishbein and I. Ajzen, Belief, Attitude, Intention, and Behavior: An Introduction to Theory and Research, Reading, MA: Addison-Wesley, 1975.

[14] W. H. Mobley, S. O. Horner, and A. T. Hollingsworth, "An evaluation of precursors of hospital employee turnover," Journal of Applied Psychology, vol. 63, pp. 408-414, 1978.

[15] R. P. Tett and J. P. Meyer, "Job satisfaction, organizational commitment, turnover intention, and turnover: Path analyses based on meta-analytic findings," Personnel Psychology, vol. 46, pp. 259-293, 1993.

[16] J. Price and J. L. Mueller, "A causal model of turnover for nurses," Academy of Management Journal, vol. 24, pp. 543-565, 1981.

[17] J. E. Mathieu and D. M. Zajac, "A review and meta-analysis of the antecedents, correlates, and consequences of organizational commitment," Psychological Bulletin, vol. 108, pp. 171-194, 1990.

[18] J. Meyer and N. Allen, "A three component conceptualization of organizational commitment," Human Resource Management Review vol. 1, pp. 61-89, 1991.

[19] J. P. Meyer and L. Herscovitch, "Commitment in the workplace: Toward a general model," Human Resource Management Review, vol. 11, pp. 299-326, 2001.

[20] J. J. Lavelle, J. Brockner, M. A. Konovsky, K. H. Price, A. B. Henley, A. Taneja, and V. Vinekar, "Commitment, procedural fairness, and organizational citizenship behaviour: A multifoci analysis," Journal of Organizational Behavior, vol. 30, pp. 337-357, 2009.

[21] J. P. Meyer, D. J. Stanley, L. Herscovitch, and L. Topolnytsky, "Affective, continuance, and normative commitment to the organization: A meta-analysis of antecedents, correlates, and consequences," Journal of Vocational Behavior, vol. 61, pp. 20-52, 2002.

[22] J. A. Colquitt, D. E. Conlon, M. J. Wesson, C. O. Porter, and K. Y. Ng, "Justice at the millennium: A meta-analytic review of 25 years of organizational justice research," Journal of Applied Psychology, vol. 86, pp. 425-445, 2001.

[23] Y. C. Charash and P. E. Spector, "The role of justice in organization: A meta-analysis," Organizational Behavior and Human Decision Processes, vol. 86, pp. 278-321, 2001.

[24] R. Cropanzano, C. A. Prehar, and P. Y. Chen, "Using social exchange theory to distinguish procedural from interactional justice," Group and Organization Management, vol. 27, pp. 324-351, 2002.

[25] M. S. Cole, J. B. Bernerth, F. Walter, and D. T. Holt, "Organizational justice and individuals' withdrawal: Unlocking the influence of emotional exhaustion," Journal of Management Studies, vol. 47, pp. 367-390, 2010

[26] J. A. Colquitt, "On the dimensionality of organizational justice: A construct validation of a measure," Journal of Applied Psychology, vol. 86 , pp. 386-400, 2001.

[27] J. Greenberg, "The social side of fairness: Interpersonal and informational classes of organizational justice," in Justice in the Workplace: Approaching Fairness in Human Resource Management, R. Cropanzano, Ed, Hillsdale, NJ: Erlbaum, 1993, pp. 79-103.

[28] E. A. Lind and T. R. Tyler, The Social Psychology of Procedural Justice. New York: Plenum Press, 1988.

[29] G. S. Leventhal, "The distribution of rewards and resources in groups and organizations" in Advances in Experimental Social Psychology, L. Berkowitz and W. Walster, Ed. New York: Academic Press, 1976, vol. 9, pp. 91-131.

[30] S. E. Hobfoll, "Conservation of resources: A new attempt at conceptualizing stress," American Psychologist, vol. 44, pp. 513-524, 1989.
[31] R. T. Mowday, R. M. Steers, and L. W. Porter, "The measurement of organizational commitment," Journal of Vocational Behavior, vol. 14, pp. 224-247, 1979.

[32] J. M. L. Poon, "Distributive justice, procedural justice, affective commitment, and turnover intention: A mediated-moderation framework," Journal of Applied Social Psychology, vol. 42, pp. 1505-1532, 2012.

[33] N. Ramamoorthy and P. C. Flood, "Gender and employee attitudes: The role of organizational justice perceptions," British Journal of Management, vol. 15, pp. 247-258, 2004

[34] Y. D. Wang, C. Yang, and K. Y. Wang, "Comparing public and private employees' job satisfaction and turnover," Public Personnel Management, vol. 51, pp. 557-573, 2012.

[35] K. J. Preacher and A. F. Hayes, "Asymptotic and resampling strategies for assessing and comparing indirect effects in multiple mediator models," Behavior Research Methods, vol. 40, pp. 879-891, 2008.

[36] J. P. Meyer, N. J. Allen, and C. A. Smith, "Commitment to organizations and occupations: Extension and test of a three-component conceptualization," Journal of Applied Psychology vol. 78, pp. 538-551, 1993.

[37] S. J. Wayne, L. M. Shore, and R. C. Liden, "Perceived organizational support and leader-member exchange: A social exchange perspective," Academy of Management Journal, vol. 40, pp. 82-111, 1997.

[38] J. F. Hair, W. C. Black, B. J. Babin, and R. E. Anderson, Multivariate Data Analysis: A Global Perspective, 7th ed, New Jersey: Pearson Prentice Hall, 2010.

[39] J. Nunnally and I. Berstein, Psychometric Theory, 3rd ed, New York: McGraw-Hill, 1994.

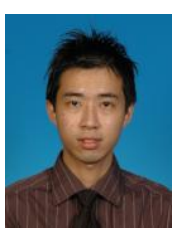

Gabriel Gim Chien Wei lives in Penang, Malaysia and he was born on 13 December, 1983. He is currently $\mathrm{Ph} . \mathrm{D}$. student at the School of Distance Education, Universiti Sains Malaysia. In 2011, he graduated with a Commonwealth Executive Masters of Business Administration (CeMBA) from Wawasan Open University. In 2007, he obtained a Bachelor of Science in Applied Accounting with First Class Honours awarded by Oxford Brookes University. In 2005, he completed all papers of The Associations of Chartered Certified Accountants (ACCA). He has worked at several multinational firms including Moores Rowland, Ernst \& Young, AMD, and Spansion before joining the academia as a lecturer at PTPL College, INTI College, and Wawasan Open University. His current research interests include organizational justice and commitment.

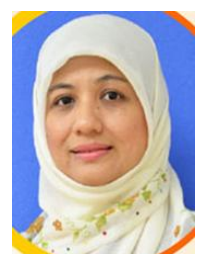

Nasina Mat Desa lives in Penang, Malaysia and she is a senior lecturer at the School of Distance Education, Universiti Sains Malaysia. She graduated from Universiti Sains Malaysia with a Doctor of Business Administration in 2009 and a Master of Business Administration in 2002. In 1995, she obtained a bachelor of Business Administration from Universiti Utara Malaysia. She has worked at several corporate organizations which include AmBank, Manpower Staffing International, Motorola, and Osram Opto Semiconductors before becoming a senior lecturer at Universiti Sains Malaysia. Her current research interests include organizational studies (workplace behaviour and leadership) and human resource management. 